\title{
Hemodiyaliz Hastalarının Serum Çinko Düzeyleri ile Hematolojik Parametreleri Arasındaki İlişki*
}

\author{
The Relationship between Serum Zinc Levels and Hematological Parameters of Hemodialysis \\ Patients
}

\author{
Gamze Yurtdaş', Efsun Karabudak², Fahri Mandıroğlu ${ }^{3}$
}

Geliş tarihi/Received: 30.03 .2018 • Kabul tarihi/Accepted: 10.04.2018

\section{ÖZET}

Amaç: Çinko, eritroid serisine spesifik gen ekspresyonunu modüle ederek eritroid hücre büyümesinde önemli bir regülatör görevi görmekte, hematopoietik kök hücrelerin ve megakaryositlerin seri gelişiminde potansiyel bir rol alarak normal eritropoez sağlamaktadır. Çinko eksikliğinin hemoglobin biyosentezini etkileyerek anemiye yol açtı̆̆ı bildirilmiştir. Bu çalışmanın amacı, hemodiyaliz hastalarının serum çinko düzeyleri ile hematolojik parametreleri arasındaki ilişkiyi değerlendirmektir.

Bireyler ve Yöntem: Çalışmaya yaşları 19-65 yıl arasında değişen özel bir diyaliz merkezinde haftada üç gün diyalize giren 36’sı erkek 29’u kadın toplam 65 yetişkin gönüllü hasta alınmıştır. Hastalara yüz yüze görüşme yöntemi ile genel bilgileri, sağlık bilgilerini içeren anket formu uygulanmış ve hastaların son üç aya ait biyokimyasal parametreleri dosyalarından alınarak kaydedilmiştir. Hastaların bir diyaliz günü-bir diyaliz dışı gün ve bir hafta sonu olmak üzere üç günlük besin tüketim kayıtları alınmıştır. Serum çinko analizi için hastalardan en az 8 saatlik açlık sonrası $10 \mathrm{~mL}$ kan örnekleri hemodiyaliz hemşiresi tarafından alınmıştır. Serum çinko analizi Selçuk Üniversitesi İleri Teknoloji Uygulama Laboratuvarı'nda ICP-MS (Inductively Coupled Plasma Mass Spectrometry) tekniği ile Perkin Elmer marka cihazda yapılmıştır.

Bulgular: Serum çinko düzeyinin ortanca ve persentil aralığı (IQR) değerleri sirasıyla erkeklerde $106.7 \mathrm{ve} 46.9 \mu \mathrm{g} / \mathrm{dL}$ kadınlarda ise 110.2 ve $48.6 \mu \mathrm{g} / \mathrm{dL}$ olarak bulunmuştur ( $\mathrm{p}>0.05$ ). Hastaların serum çinko düzeyleri ile hemoglobin ( $\mathrm{r}=0.344$, $\mathrm{p}=0.005)$, hematokrit $(\mathrm{r}=0.336, \mathrm{p}=0.006)$, total demir bağlama kapasitesi $(\mathrm{r}=0.302, \mathrm{p}=0.014)$ düzeyleri arasında pozitif yönde ilişki bulunmuştur. Serum çinko düzeyleri ile serum demir $(r=0.072, p=0.567)$ ve serum ferritin $(r=0.073, p=0.552)$ düzeyleri arasında ilişki saptanmamıştır. Hastaların serum çinko düzeyleri ile diyetle demir alımı $(r=-0.030, p=0.810)$ arasında ilişki bulunmamıştır.

Sonuç: Hemodiyaliz hastalarında serum çinko düzeyleri ile bazı hematolojik parametreler arasında korelasyon olması, serum çinko düzeyinin bu hastalarda sıklıkla görülen anemi ile ilişkili olabileceğini düşündürmektedir.

Anahtar kelimeler: Hemodiyaliz, serum çinko düzeyi, hematolojik parametreler

1. İletişim/Correspondence: Gazi Üniversitesi, Sağlık Bilimleri Fakültesi, Beslenme ve Diyetetik Bölümü, Beşevler, Ankara, Türkiye • E-posta: gmzyurtdas@hotmail.com (ㄱ) https://orcid.org/0000-0001-5410-7231
2. Gazi Üniversitesi, Sağlık Bilimleri Fakültesi, Beslenme ve Diyetetik Bölümü, Beşevler, Ankara, Türkiye (1) https://orcid.org/0000-0002-4210-1657

3. RFM Diyaliz Merkezi, Ankara, Türkiye 으 https://orcid.org/0000-0003-3843-5328

\footnotetext{
* Bu çalışma, Uzm Dyt. Gamze Yurtdaş tarafindan “Uluslararası Sağllk Beslenme Kongresi-Gastrointestinal Hastallklar” toplantısında 5-7 Ekim 2017 tarihinde sözel bildiri olarak
} sunulmuştur. 


\section{ABSTRACT}

Aim: Zinc modulates the expression of zinc-specific erythroid-specific genes, plays an important role in the growth of erythroid cells, and provides normal erythropoiesis with a potential role in the serial development of hematopoietic stem cells and megakaryocytes. Zinc deficiency has been reported to cause anemia by affecting hemoglobin biosynthesis. The aim of this study is to evaluate the relationship between serum zinc levels and hematological parameters of hemodialysis patients.

Subjects and Methods: The study was conducted on a total of 65 adult volunteer patients (ages between 19 and 65 years), 36 men and 29 women who received dialysis treatment three days a week in special dialysis center. A questionnaire including general information, health information was applied with the face to face interview method and biochemical parameters of the last three months were recorded from the files. Food consumptions of the patients for three days (one dialysis day, nondialysis day and one weekend) were recorded. For serum zinc analysis, $10 \mathrm{~mL}$ blood samples were taken by hemodialysis nurses after at least 8 hours fasting from patients. Serum zinc analysis was performed in Selcuk University Advanced Technology Application Laboratory with ICP-MS (Inductively Coupled Plasma Mass Spectrometry) technique in Perkin Elmer device.

Results: Median and interquantile range (IQR) values of serum zinc levels were 106.7 and $46.9 \mu \mathrm{g} / \mathrm{dL}$ in men and 110.2 and $48.6 \mu \mathrm{g} / \mathrm{dL}$ in women, respectively ( $\mathrm{p}>0.05$ ). There was a positive correlation between serum zinc levels and hemoglobin $(\mathrm{r}=0.344, \mathrm{p}=0.005)$, hematocrit $(\mathrm{r}=0.336, \mathrm{p}=0.006)$, total iron binding capacity $(\mathrm{r}=0.302, \mathrm{p}=0.014)$. Serum zinc levels were not correlated with serum iron $(r=0.072, p=0.567)$ and serum ferritin $(r=0.073, p=0.552)$. There was no relationship between serum zinc levels and iron intake of the patients $(\mathrm{r}=-0.030, \mathrm{p}=0.810)$.

Conclusion: Correlation between serum zinc levels and some hematological parameters in hemodialysis patients suggests that serum zinc levels may be associated with anemia, which is common in these patients.

Keywords: Hemodialysis, serum zinc level, hematological parameters

\section{GíRiş}

Çinko, bitki ve hayvanların büyümesi ve sağlığı için elzem olup vücutta demirden sonra en çok bulunan eser elementtir $(1,2)$. Alkol dehidrojenaz, karbonik anhidraz, alkalen fosfataz, RNA ve DNA polimerazlar, süperoksid dismutaz, timidin kinaz, karboksipeptidazlar gibi yaklaşık 300 enzimin yapısında bulunmaktadır. Çinko birçok enzimi aktivite edebilmekte veya baskılayabilmektedir. Steroid hormonlarının, tiroid hormonlarının ve kalsiterol reseptörlerinin transkripsiyon faktörlerine bağlanmaktadır. Biyolojik sistemlerde sadece +2 değerlikli olarak bulunmakta, demir ve bakırdan farklı olarak oksidasyon veya redüksiyona uğramamaktadır (2).

Çinko ayrıca gen ekspresyonunda yapısal ve enzimatik rol oynamaktadır (2). Eritroid serisine spesifik gen ekspresyonunu modüle ederek eritroid hücre büyümesinde önemli bir regülatör görevi gören, eritropoez sirasında transkripsiyonel düzenlemeyi gerçekleştiren, olgunlaşmamış eritroblastların çoğalmasını destekleyen growth factor independent 1B (GFI1B) çinko parmak proteininin yapısında bulunmakta ve hematopoietik kök hücrelerin ve megakaryositlerin seri gelişiminde potansiyel bir rol alarak normal eritropoez sağlamaktadır (3).

Kronik böbrek yetmezliği (KBY) hastalarında çinko yetersizliği prevalansı yüksek olup \%40-78 oranında değiştiği bildirilmektedir $(4,5)$. Bu hastalarda çinko yetersizliği nedenleri arasında, diyetle düşük çinko alımı, diyetle düşük protein alımının çinko emilimini azaltması, proteinüri nedeniyle çinkonun proteinçinko kompleksinin atılımına neden olması, böbrek işlevlerinin azalması yer almaktadır (6). 
Anemi, KBY hastalarında glomerüler filtrasyon hızının düşmesine ve eritropoetin azalmasına bağlı olarak sık görülen bir diğer sorundur (7). Özellikle hemodiyaliz hastalarında demirin diyaliz membranına bağlanması, gizli intestinal kan kayıpları, rutin tahliller için sık sık kan alınması ve hemodiyaliz işlemlerinin sonlandırılmasında diyalizörde kan tutulması gibi etmenler demir eksikliği anemisine yol açmaktadır. Rekombinant insan eritropoietin (EPO) ile tedavi, yeterli demir desteği yapılmadığında eritropoezi arttırarak hemoglobine bağlı demir depolarını azaltabilmektedir (8). Hemoglobin düzeyinin $11 \mathrm{mg} /$ dL'nin altına düşmesi ise morbidite ve mortalite ile ilişkilendirilmektedir (9). Yapılan bir çalışmada, çinko yetersizliğinin hemoglobin biyosentezini etkileyerek anemiye yol açtığı bildirilmiştir (10). Bu çalışma, hemodiyaliz hastalarının serum çinko düzeyleri ile hematolojik parametreler arasındaki ilişkiyi değerlendirmek amacıyla planlanmış ve yapılmıştır.

\section{BİREYLER VE YÖNTEM}

$\mathrm{Bu}$ çalışma, 2016 yllında Ankara ilinde özel bir diyaliz merkezinin üç farklı şubesinde yapılmıştır. Çalışma en az bir yıldır haftada üç gün hemodiyaliz tedavisi alan, yaşları 19-65 yıl arasında olan 36'sı erkek (\%55.4), 29’u (\%44.6) kadın toplam 65 hasta üzerinde yürütülmüştür. Katabolik ilaç kullanan, antioksidan ve beslenme desteği alan, hepatit, kanser, tiroid, karaciğer, diabetes mellitus, kalp hastalıkları ile inflamasyonu olan bireyler çalışmaya dahil edilmemiştir. Hastalara çalışmaya gönüllü katıldıklarına dair yazılı onam formu imzalatılmıştır. Bu çalışma için, Zekai Tahir Burak Kadın Sağlığı ve Eğitim Araştırma Hastanesi Klinik Araştırmalar Etik Kurulu tarafından "Etik Kurul Onayı" alınmıştır (29.11.2016 tarihli ve KA48/2016 sayılı).

\section{Antropometrik Ölçümler}

Hastaların vücut ağırlıkları $\pm 0.1 \mathrm{~kg}$ hassasiyetindeki Medical Scale DR-Mod 85 marka elektronik tartı ile ölçülmüştür. Hemodiyalize giren hastaların vücut ağırlığında kuru ağırlık (diyaliz çıkış ağırlığı) değerleri kullanılmıştır. Kuru ağırlık hastanın nefes darlığı veya vücudunda ödem olmadığı, kan basıncının normale düştüğü diyaliz çıkışındaki ağırlığıdır (11). Hastaların boy uzunluklarının ölçümü, esnemeyen çelik şerit metre ile topuklar bitişik, sırt ve omuz başları dik durumdayken, başın en yüksek üst noktasından yere kadar olan mesafenin ölçümüyle yapılmıştır (12). Beden Kütle İndeksinin (BKİ) hesaplanmasında, BKİ=[Ağırlık (kg)/Boy uzunluğu $\left.\left(\mathrm{m}^{2}\right)\right]$ formülü kullanılmıştır (11,12).

\section{Besin Tüketim Durumunun Saptanması}

Besin tüketim durumunun saptanması için hastalardan bir günü hafta içi, bir günü diyaliz günü, bir günü hafta sonu olmak üzere üç günlük besin tüketim kaydı alınmıştır. Besin tüketim kayıtların nasıl doldurulacağı hasta ve/veya yakınına açıklanmıştır. Tüketilen yiyecek ve içeceklerin ölçü ve miktarlarının belirlenmesinde "Yemek ve Besin Fotoğraf Kataloğu" (13) kullanılmıştır. Hastaların tükettikleri yemeklerin içerisine giren besin maddelerinin miktarları hasta tarafindan belirtilmediği takdirde "Standart Yemek Tarifleri” (14) kitabından yararlanılarak hesaplanmıştır. Günlük diyetle alınan enerji ve besin ögeleri, Türkiye için geliştirilen "Bilgisayar Destekli Beslenme Programı, Beslenme Bilgi Sistemleri Paket Programı (BEBİS)” kullanılarak analiz edilmiştir (15).

\section{Biyokimyasal ve Hematolojik Parametreler}

Hastaların, kan örnekleri diyaliz merkezinde çalışan hemodiyaliz hemşiresi tarafından alınmıştır. "Diyaliz Merkezleri Hakkında Yönetmelik”te (Resmi Gazete Tarihi: 18.06.2010 Resmi Gazete Sayısı: 27615) yayınlanan rutinde alınan aylık diyaliz girişindeki biyokimyasal test değerleri [kan glukozu, kan üre veya üre nitrojeni, serum kreatinin, potasyum, sodyum, kalsiyum ve fosfor düzeyi, alanin aminotransferaz (ALT), total protein ve albümin, hemogram], geçmiş üç ayda değerlendirilen rutin biyokimyasal test değerleri [serum demiri, total demir bağlama kapasitesi (TDBK), ferritin, ürik asit, C-reaktif protein] ve geçmiş altı ayda değerlendirilen rutin biyokimyasal test değerleri [İntact PTH, alkalen fosfataz, lipitler (total kolesterol, LDL-kolesterol, HDL-kolesterol, trigliserit] diyaliz 
merkezinin kayıtlarındaki bilgisayar ortamından alınmıştır.

Serum çinko analizi ise Selçuk Üniversitesi İleri Teknoloji Uygulama Laboratuvarı'nda ICP-MS (Inductively Coupled Plasma Mass Spectrometry) tekniği ile Perkin Elmer marka cihazda yapılmıştır. Serum numunelerinin 0.1 ile $1 \mathrm{~g}$ arasında tartımı yapıldıktan sonra üzerlerine $10 \mathrm{~mL} \mathrm{HNO}_{3}$ eklenip Cem Mars-5 marka mikrodalga cihazında 800W \%100 güç ile 35 dakika boyunca $200^{\circ} \mathrm{C}$ de yakma-çözme işlemi uygulanmış ve ardından numuneler ICP-MS cihazında okunmuştur. ICP-MS cihazında sekiz ayrı noktada kalibrasyon eğrisi çizilmiş kalibrasyon $\mathrm{R}^{2}$ si 0.999’un üzerinde tutulmuştur.

\section{İstatistiksel Değerlendirme}

Verilerin istatistiksel değerlendirilmesinde Windows ortaminda SPSS 22.0 istatistiksel paket programı kullanılmıştır. $\mathrm{Bu}$ araştırmaya katılan bireylerden elde edilen ölçümlerle belirlenen veriler için ortalama \pm standart sapma $\left(\overline{\mathrm{X}}_{ \pm S}\right)$ ortanca ve persentil aralığı (interquantile range-IQR) değerleri hesaplanmış ve nitel veriler sayı (n) ve yüzde (\%) olarak gösterilmiştir. Verilerin normal dağılıp dağılmadığı $n \geq 50$ için Kolmogorov Smirnov testi kullanılarak değerlendirilmiştir. Normal dağılıma uygun olan ölçüm değerleri için parametrik yöntemler kullanılmıştır. Parametrik yöntemlere uygun şekilde, bağımsız iki grubun ölçüm değerleri ile karşılaştırılmasında “İki Bağımsız Grup t Testi” (t tablo değeri) yöntemi kullanılmıştır. Parametrik olmayan

Tablo 1. Hastaların genel özellikleri

\begin{tabular}{|c|c|c|c|c|c|c|c|}
\hline \multirow{2}{*}{ Değişkenler } & \multicolumn{2}{|c|}{ Erkek $(n=36)$} & \multicolumn{2}{|c|}{ Kadın $(n=29)$} & \multicolumn{2}{|c|}{ Toplam $(n=65)$} & \\
\hline & $\mathbf{n}$ & $\%$ & $\mathbf{n}$ & $\%$ & $\mathbf{n}$ & $\%$ & \\
\hline \multicolumn{8}{|l|}{ Medeni durum } \\
\hline Evli & 35 & 97.2 & 20 & 69 & 55 & 84.6 & \multirow{2}{*}{$\begin{array}{c}x^{2}=9.851 \\
p=0.002\end{array}$} \\
\hline Bekar/dul/boşanmış & 1 & 2.8 & 9 & 31 & 10 & 15.4 & \\
\hline \multicolumn{8}{|l|}{ Eğitim durumu } \\
\hline Okur-yazar değil & 1 & 2.8 & 8 & 27.6 & 9 & 13.8 & \multirow{4}{*}{$\begin{array}{c}x^{2}=11.462 \\
\mathrm{p}=0.022\end{array}$} \\
\hline İlkokul & 20 & 55.6 & 12 & 41.4 & 32 & 49.2 & \\
\hline Ortaokul & 12 & 33.3 & 5 & 17.2 & 17 & 26.2 & \\
\hline Lise & 3 & 8.3 & 4 & 13.8 & 7 & 10.8 & \\
\hline \multicolumn{8}{|l|}{ KBY nedeni } \\
\hline Hipertansiyon & 17 & 47.2 & 11 & 37.9 & 28 & 43.1 & \multirow{5}{*}{$\begin{array}{l}x^{2}=8.777 \\
p=0.553\end{array}$} \\
\hline Glomerülonefrit & 3 & 8.3 & 4 & 13.9 & 7 & 10.8 & \\
\hline Polikistik böbrek & 2 & 5.6 & 2 & 6.9 & 4 & 6.2 & \\
\hline Etiyolojisi bilinmiyor & 8 & 22.2 & 8 & 27.6 & 16 & 24.6 & \\
\hline Diğer nedenler & 6 & 16.7 & 4 & 13.7 & 10 & 15.3 & \\
\hline \multicolumn{8}{|l|}{ Kullanılan ilaçlar* } \\
\hline Antihipertansif & 18 & 50 & 16 & 55.2 & 34 & 52.3 & \\
\hline Demir preparatları & 25 & 69.4 & 26 & 89.7 & 51 & 78.5 & \\
\hline Vitamin-mineral kompleksi & 18 & 50 & 22 & 75.9 & 40 & 61.5 & \\
\hline Antifosfor & 30 & 83.3 & 23 & 79.3 & 53 & 81.5 & \\
\hline Antipotasyum & 3 & 8.3 & 1 & 3.4 & 4 & 6.2 & \\
\hline Ketoasit/elzem aminoasit & 13 & 36.1 & 8 & 27.6 & 21 & 32.3 & \\
\hline Aspirin & 15 & 41.7 & 16 & 55.2 & 31 & 47.7 & \\
\hline
\end{tabular}


yöntemlere uygun şekilde, iki bağımsız grubun ölçüm değerleri ile karşılaştırılmasında "Mann-Whitney U Testi” (Z tablo değeri) kullanılmıştır. Nitel değişkenler için ki-kare (Chi-square) testi veya çapraz tablolarda beklenen değerlerin 5’ten küçük olduğu durumlarda Fisher'in kesin ki-kare testi (Fisher's Exact Test) uygulanmıştır. Değişkenler arasındaki ilişki, iki yönlü korelasyon testi (Pearson) ile araştırılmıştır. Tüm istatistiksel testlerde en düşük anlamlılık düzeyi 0.05 olarak anlamlı kabul edilmiştir.

\section{BULGULAR}

Çalışmaya katılan KBY olan hastaların 36'sı (\%55.4) erkek, 29’u (\%44.6) kadındır. Erkek hastaların yaş ortalaması $51.8 \pm 9.64$ yıl, kadınların yaş ortalaması $52.6 \pm 11.41$ yll, toplam yaş ortalaması ise $52.2 \pm 10.39$ yıldır. Erkek hastaların diyalize girme süreleri $89.6 \pm 85.75$ ay, kadın hastaların ise $107.3 \pm 60.20$ ay olarak bulunmuştur (Tabloda belirtilmemiştir.)

Çalışmaya katılan bireylerin genel özellikleri Tablo 1'de gösterilmiştir. Hastaların \%84.6'sı evli, \%15.4'ü bekardır. Hastaların \%49.2'si ilkokul, \%26.2'si ortaokul mezunudur. Çalışmaya katılan hastaların \%43.1'inin KBY hastalığının primer nedeninin hipertansiyon, \%10.8'inin glomerülonefrit, \%6.2'sinin polikistik böbrek hastalığı olduğu belirlenmiştir.

Hastaların \%52.3'ü antihipertansif, \%78.5’i demir preparatları, \%61.5’i vitamin-mineral kompleksi \%81.5’i antifosfor, \%6.2'si antipotasyum ilacl kullanmaktadır (Tablo 1).

Tablo 2'de hastaların cinsiyete göre antropometrik ölçümleri, biyokimyasal değerleri ve günlük diyetle alınan enerji ile bazı makro ve mikro besin ögelerinin ortalama \pm standart sapma veya ortanca (IQR) değerleri verilmiştir. Erkek hastaların ortalama BKI değeri $24.6 \pm 2.92 \mathrm{~kg} / \mathrm{m}^{2}$, kadınların ise $23.3 \pm 4.42 \mathrm{~kg}$ / $\mathrm{m}^{2}$ 'dir. Cinsiyete göre BKİ değeri arasında istatiksel olarak anlamlı bir fark yoktur ( $p>0.05)$. Serum çinko düzeyi ortanca ve IQR değerleri sirasıyla erkeklerde 106.7 ve $46.9 \mu \mathrm{g} / \mathrm{dL}$, kadınlarda 110.2 ve $48.6 \mu \mathrm{g} / \mathrm{dL}$ 'dir.

Tablo 2. Hastaların cinsiyete göre antropometrik ölçümleri, biyokimyasal değerleri ve günlük alınan enerji ve bazı makro mikro besin ögelerinin ortalama \pm standart sapma $\left(\overline{\mathrm{X}}_{ \pm} \mathrm{S}\right)$ veya ortanca (IQR) değerleri

\begin{tabular}{|c|c|c|c|}
\hline \multirow{2}{*}{ Değişken } & Erkek $(n=36)$ & Kadın $(n=29)$ & \multirow{2}{*}{$\mathbf{p}$} \\
\hline & $\overline{\bar{X}} \pm S$ veya ortanca $(I Q R)$ & $\overline{\mathrm{X}} \pm \mathrm{S}$ veya ortanca (IQR) & \\
\hline \multicolumn{4}{|l|}{ Antropometrik ölçümler } \\
\hline Diyaliz çıkış ağırlığı (kg) & $71.3 \pm 9.63$ & $58.6 \pm 10.74$ & $0.000^{*}$ \\
\hline Boy uzunluğu (cm) & $169.8 \pm 4.79$ & $158.6 \pm 6.20$ & $0.000^{*}$ \\
\hline BKİ $\left(\mathrm{kg} / \mathrm{m}^{2}\right)$ & $24.6 \pm 2.92$ & $23.3 \pm 4.42$ & 0.148 \\
\hline \multicolumn{4}{|l|}{ Biyokimyasal bulgular } \\
\hline Serum çinko $(\mu \mathrm{g} / \mathrm{dL})$ & $106.7(46.9)$ & $110.2(48.6)$ & 0.864 \\
\hline Hemoglobin (g/dL) & $11.6 \pm 1.32$ & $11.1 \pm 0.91$ & 0.084 \\
\hline Hematokrit (\%) & $37.4 \pm 4.74$ & $35.8 \pm 3.21$ & 0.124 \\
\hline TDBK $(\mu \mathrm{g} / \mathrm{dL})$ & $239.6 \pm 49.94$ & $234.0 \pm 77.12$ & 0.725 \\
\hline Serum demir $(\mu \mathrm{g} / \mathrm{dL})$ & $66.3 \pm 24.17$ & $69.1 \pm 31.72$ & 0.690 \\
\hline Ferritin (g/dL) & $580.8 \pm 355.95$ & $775.4 \pm 491.02$ & 0.069 \\
\hline \multicolumn{4}{|l|}{ Diyetle alım } \\
\hline Enerji (kkal) & $1658 \pm 434.77$ & $1190 \pm 230.28$ & $0.000^{*}$ \\
\hline Karbonhidrat (TE\%) & $49.8 \pm 5.81$ & $46.5 \pm 8.45$ & $0.000^{*}$ \\
\hline Protein (TE \%) & $13.8 \pm 2.08$ & $13.7 \pm 2.16$ & 0.847 \\
\hline Toplam yağ (TE \%) & $36.2 \pm 6.19$ & $39.7 \pm 7.37$ & $0.041^{*}$ \\
\hline Demir (mg) & $8.8 \pm 2.44$ & $6.6 \pm 1.95$ & $0.000^{*}$ \\
\hline Çinko (mg) & $7.4 \pm 2.42$ & $5.4 \pm 2.15$ & $0.000^{*}$ \\
\hline
\end{tabular}


Cinsiyete göre serum çinko, hemoglobin, hemotokrit, TDBK, demir, ferritin değerleri arasında istatistiksel olarak anlamlı fark yoktur ( $p>0.05)$.

Erkek hastaların diyetle aldıkları günlük enerji $(1658 \pm 434.77 \mathrm{kkal})$ kadınlardan $(1190 \pm 230.28 \mathrm{kkal})$ daha yüksektir $(\mathrm{p}<0.05)$. Enerjinin karbonhidrattan gelen oranı erkeklerde $(\% 49.8 \pm 5.81)$ kadınlardan (\%46.5 \pm 8.45$)$ anlamlı derecede daha yüksektir $(p<0.05)$. Enerjinin yağdan gelen oranı erkeklerde ortalama \%36.2 \pm 6.19 iken, kadinlarda ortalama \%39.7 \pm 7.37 'dir $(\mathrm{p}<0.05)$. Erkek hastaların diyetle günlük demir (8.8 $\pm 2.44 \mathrm{mg})$, çinko $(7.4 \pm 2.42 \mathrm{mg})$ alım ortalamaları, kadın hastaların demir $(6.6 \pm 1.95 \mathrm{mg})$ ve çinko $(5.4 \pm 2.15 \mathrm{mg})$ alım ortalamalarından anlamlı derecede daha yüksektir ( $<<0.05)$ (Tablo 2).

Hastaların serum çinko düzeyleri ile hematolojik parametreler ve bazı mikro besin ögeleri arasındaki ilişki Tablo 3’te verilmiştir. Hastaların serum çinko düzeyleri ile hemoglobin, hematokrit, TDBK düzeyleri arasında pozitif yönlü ilişki saptanmıştır $(p<0.05)$. Hastaların serum çinko düzeyi ile diyet demir (mg) ve çinko (mg) arasında ilişki yoktur ( $p>0.05)$.

Tablo 3. Hastaların serum çinko düzeyleri ile hematolojik parametreler ve bazı mikro besin ögeleri arasındaki ilişki

\begin{tabular}{lcc}
\hline & \multicolumn{2}{c}{ Serum çinko $(\boldsymbol{\mu g} / \mathbf{d L})$} \\
\cline { 2 - 3 } & $\mathbf{r}$ & $\mathbf{p}$ \\
\hline Hemoglobin $(\mathrm{g} / \mathrm{dL})$ & 0.344 & $0.005^{* *}$ \\
Hematokrit $(\%)$ & 0.336 & $0.006^{* *}$ \\
TDBK $(\mu \mathrm{d} / \mathrm{dL})$ & 0.302 & $0.014^{* *}$ \\
Serum demir $(\mu \mathrm{g} / \mathrm{dL})$ & 0.072 & 0.567 \\
Ferritin $(\mathrm{g} / \mathrm{dL})$ & 0.073 & 0.552 \\
Demir $(\mathrm{mg})($ diyet) & -0.030 & 0.810 \\
Çinko $(\mathrm{mg})$ (diyet) & -0.090 & 0.474 \\
\hline
\end{tabular}

${ }^{*} p<0.05$, TDBK:Total Demir Bağlama Kapasitesi

\section{TARTIŞMA}

Çinko, besin alımının düzenlenmesinde ve birçok enzimin yapısında bulunun önemli bir mikro besin ögesidir. KBY hastalarında çinko yetersizliği sıklıkla görülmektedir $(4,5) . \mathrm{Bu}$ hastalarda çinko yetersizliği nedenleri arasında, diyetle düşük çinko alımı, diyetle düşük protein alımının çinko emilimini azaltması, proteinüri nedeniyle çinkonun proteinçinko kompleksinin atılımına neden olması, böbrek işlevlerinin azalması yer almaktadır (6). Yetişkinler için serum çinko düzeyinin normal değerleri 80-120 $\mu \mathrm{g} / \mathrm{dL}$ olarak kabul edilmektedir (16). Yapılan bu çalışmada, serum çinko analizi için analitik hataları ortadan kaldıran, yüksek doğrulukta modern ve duyarlı bir yöntem olan ICP-MS kullanılmış olup serum çinko düzeyi ortanca ve IQR değeri sırasıyla erkeklerde 106.7 ve $46.9 \mu \mathrm{g} / \mathrm{dL}$, kadınlarda 110.2 ve $48.6 \mu \mathrm{g} / \mathrm{dL}$ olarak bulunmuştur ( $\mathrm{p}>0.05$ ) (Tablo 2). Uslu ve arkadaşları (17) çalışmalarında, bu çalışmada elde edilen sonuçlara paralel olarak hemodiyaliz hastalarının serum çinko düzeylerini 104.4 \pm 41.63 $\mu \mathrm{g} / \mathrm{dL}$, sağllklı kontrol grubunu 129.5 $\pm 50.55 \mu \mathrm{g} / \mathrm{dL}$ olarak bulmuştur. Yine benzer şekilde başka bir çalışmada, hemodiyaliz hastaların ortalama serum çinko düzeyleri 107.1 $\pm 21.58 \mu \mathrm{g} / \mathrm{dL}$, sağlıklı kontrol grubunda $206.91 \pm 25.38 \mu \mathrm{g} / \mathrm{dL}$ olarak rapor edilmiştir (18). Çinko analizi için ICP-MS yönteminin kullanıldığı bir çalışmada, hemodiyaliz hastalarında plazma çinko düzeyleri eritrositlerde ve tam kanda yüksek, plazmada düşük olarak bulunmuştur (19). Çinko ve diğer iz elementlerin farklı biyolojik örneklerdeki sonuçlarının farklı olması dikkatli yorumlamayı gerektirdiği bildirilmiştir (17). Zima ve arkadaşları (20) çalışmalarında, yaşanılan bölgesel değişikliklerin, toprak ve suyun çevresel kontaminasyonun ve diyet alışkanlıklarının son dönem böbrek yetmezliği olan hastaların iz element düzeylerini önemli düzeyde etkileyebileceğini rapor etmişlerdir. Bu çalışmada, hemodiyaliz hastalarının serum çinko düzeylerinin normal aralıkta olduğu saptanmıştır. Hastaların kan değerleri sürekli uzman bir doktor tarafından kontrol altında tutulduğundan ve çinko eksikliği durumunda çinko desteği yapıldığından dolayı serum çinko düzeylerinin normal aralıkta olduğu düşünülmektedir.

Glomerüler filtrasyon hızının düşmesine ve eritropoetin (EPO) yapımının azalmasına bağlı olarak KBY hastalarında anemi sıklıkla ortaya çlkmaktadır (7). Hemoglobin düzeyinin 11 mg/dL'nin 
altında olmasının morbidite ve mortalite riskiyle ilişkili olduğu bildirilmiştir (9). Bu çalışmada, erkek hastaların hemoglobin ortalama değerleri 11.6 \pm 1.32 $\mathrm{g} / \mathrm{dL}$, kadınlarda $11.1 \pm 0.91 \mathrm{~g} / \mathrm{dL}$ olarak bulunmuştur ( $p>0.05$ ). Erkek hastalarda ortalama ferritin değerleri $580.8 \pm 355.95 \mathrm{~g} / \mathrm{dL}, \quad$ kadınlarda $775.4 \pm 491.02 \mathrm{~g} / \mathrm{dL}$ olarak belirlenmiştir ( $>0.05$ ) (Tablo 2). Hemodiyaliz hastaları ile yapılan bir çalışmada, hastaların hemoglobin düzeyi $10.8 \pm 1.8 \mathrm{~g} / \mathrm{dL}$ ve ferritin düzeyi $508.3 \pm 346.4 \mathrm{ng} / \mathrm{mL}$ olarak saptanmıştır (21). Rakıcıoğlu ve arkadaşları (22) çalışmalarında, hemodiyaliz hastalarında hemoglobin düzeyini $11.6 \mathrm{~g} / \mathrm{dL}$ olarak bildirmişlerdir. Bu çalışmada hastaların hemoglobin düzeyinin normal aralıkta olmasının nedeninin hastaların çoğunun demir preparatı ve eritopoetin tedavisi almalarından ileri geldiği düşünülmektedir.

Hemodiyaliz hastalarında günlük diyetle erkekler için $8 \mathrm{mg}$ ve kadınlar için $15 \mathrm{mg}$ demir almaları önerilmektedir (23). Bu çalışmada diyetle günlük demir alımının erkeklerde $(8.8 \pm 2.44 \mathrm{mg})$ kadınlardan $(6.6 \pm 1.95 \mathrm{mg})$ daha yüksek olduğu belirlenmiştir $(p<0.05)$ (Tablo 2). Hemodiyaliz hastaları ile yapılan bir çalışmada hastalarının günlük diyetle demir alımları 8.61ะ4.4 mg olarak bulunmuş ve kadınların \%70'inin demiri yetersiz, erkeklerin \%56.5'unun yeterli miktarda aldıkları saptanmıştır (24). Bu hastalarda demir düzeyini normal sinırlar içerisinde tutmak için hastaların düzenli olarak doktor ve diyetisyen kontrolünde olmaları önem taşımaktadır.

Hemodiyaliz hastalarında kadınlar için günlük 8-12 mg, erkekler için 10-15 mg çinko alımı önerilmektedir (23). Bu çalışmada günlük diyetle çinko alımı erkeklerde $7.4 \pm 2.42 \mathrm{mg}$, kadın hastalarda $5.4 \pm 2.15 \mathrm{mg}$ olarak belirlenmiş ve cinsiyetler arasındaki farklılık anlamlı bulunmuştur $(\mathrm{p}<0.05) \quad($ Tablo 2). Erkek hastaların günlük çinko alım miktarının önerilen değerin altında olması çinko kaynağı olan et, balık, süt gibi protein kaynaklarının hastaların serum fosfor değerlerini dengede tutmak için kısıtlanmaları ile açıklanabilir. Yetersiz protein/enerji alan hemodiyaliz hastalarında ve çinko eksikliğini bozulmuş tat veya koku, ciltte kırılganlık, iktidarsızlık gibi belirtilerle gösteren durumlarda 3-6 ay için günlük 50 mg çinko desteği önerilmektedir (23). Bu hastalarda uzman doktor tarafından çinko eksikliği saptandığında çinko desteği yapılmaktadır.

Bu çalışmada da serum çinko düzeyleri ile hemoglobin, hematokrit, TDBK değerleri arasında pozitif yönlü ilişki saptanmıştır $(\mathrm{p}<0.05)$ (Tablo 3). Bu çalışmaya uyumlu şekilde, birçok çalışmada diyaliz tedavisi alan hastalarda serum çinko düzeyi ile hematolojik parametreler (kırmızı kan hücresi sayısı, hemoglobin düzeyi, hematokrit) arasında pozitif ilişki olduğu gösterilmiştir (10,25,26).

Hemodiyaliz hastalarında serum çinko düzeyleri ile bazı hematolojik parametreler arasında korelasyon olması, serum çinko düzeyinin bu hastalarda sıklıkla görülen anemi ile ilişkili olabileceğini düşündürmektedir. Çinko ve demir eksikliği olan hastaların örneklemini oluşturduğu benzer çalışmalar yapılarak bu ilişki konusunda daha net yorumlara gidilmelidir. Hemodiyaliz hastalarında demir ve çinko minerallerinden birisinin eksikliği durumunda diğerinin yetersizliğinin olabileceği göz önünde bulundurulmalı ve alanında uzman sağlık profesyonelleri bu konuda gerekli tedbirleri almalıdır.

Çıkar çatışması - Conflict of interest: Yazarlar çıkar çatışması olmadığını beyan ederler. - The authors declare that they have no conflict of interest.

\section{KAYNAKLAR}

1. Sencer E, Orhan Y. Klinik Beslenme. Birinci Baskı. İstanbul, Medikal Yayıncılık, 2005.

2. Onat T, Emerk K, Sözmen EY. İnsan Biyokimyası. Palme Yayıncllik, 2002.

3. Kelkitli E, Özturk N, Aslan NA, Kılıç-Baygutalp N, Bayraktutan Z, Kurt N, et al. Serum zinc levels in patients with iron deficiency anemia and its association with symptoms of iron deficiency anemia. Ann Hematol 2016;95(5):751-756.

4. Lee H. Trace metals abnormalities in hemodialyzed patients, relationship with medications. Artif Organs 2000;24(11):841-844.

5. Dvornik S, Cuk M, Racki S, Zaputovic L. Serum zinc concentrations in the maintenance hemodialyzed patients. Coll Antropol 2006;30(1):259-263.

6. Lobo JC, Aranha LN, Moraes C, Brito LC, Mafra D. 
Linking zinc and leptin in chronic kidney disease: future directions. Biol Trace Elem Res 2012;146(1):1-5.

7. Bakkaloğlu S, Tumer N, Ekim M, Yalçınkaya F. Kronik böbrek yetmezliğinde anemi ve eritropoetin kullanımı. Turk Neph Dial Transpl 1998;2:54-58.

8. Kalantar-Zadeh, K., Kopple, J.D. Chapter 32 - Nutritional Management of Maintenance Hemodialysis Patients. In: Nutritional Management of Renal Disease. Third ed. 2013; 503-538.

9. Mann J. What are the short-term and long-term consequences of anaemia in CRF patients? Nephrol Dial Transplant 1999;14(suppl 2):29-36.

10. Grzegorzewska AE, Mariak I. Zinc as a marker of nutrition in continuous ambulatory peritoneal dialysis patients. Adv Perit Dial 2001;17:223-229.

11. Pekcan G. Beslenme durumunun saptanması (Eds:Baysal A, Aksoy M, Besler T, Bozkurt N, Keçecioğlu S, Kutluay Merdol T ve ark). Diyet El Kitabı. Hatiboğlu Basın ve Yayın san. Tic.Ltd.Şti, Ankara, 2011.s.67-141.

12. Gibson RS. Principles of Nutritional Assessment. Oxford Univerity Press. 1990.p.40-1.

13. Rakıcıoğlu N, Tek Acar N, Ayaz A, Pekcan G. Yemek ve Besin Fotoğraf Kataloğu-Ölçü ve Miktarlar. Ata Ofset Matbaacılık, Ankara, 2009.

14. Merdol Kutluay T. Toplu Beslenme Yapılan Kurumlar için Standart Yemek Tarifeleri. Hatiboglu Yayınevi, Ankara, 2003.

15. Bebis (Beslenme Bilgi Sistemi) Nutrition Data Base Software. Data base: The German Food Code and Nutrient Data Base (BLS II.3, 1999) with additions from USDA-sr and other sources. İstanbul, 2004.

16. Burtis CA, Ashwood ER, Bruns D. Tietz Textbook of Clinical Chemistry and Molecular Diagnostics. Fifth ed. United States of America: Elsevier/Saunders, 2012. p.1523-1525.
17. Uslu S, Çolak Ö, Demir TA, Berber A, Özdemir G, Alataş Ö. Hemodiyaliz hastalarında kardiak belirteçler ve iz elementler. Türk Klinik Biyokimya Derg 2005;3(3):85-93.

18. Turkmen K, Ecder T. The relationship between serum zinc levels and tumor markers in hemodialysis patients. Eur J Gen Med 2014;11(3):174-178.

19. Zima T, Mestek O, Němeček K, Bártová V, Fialová J, Tesař $\mathrm{V}$, et al. Trace elements in hemodialysis and continuous ambulatory peritoneal dialysis patients. Blood Purif 1998;16(5):253-260.

20. Zima T, Tesar V, Mestek O, Nemecek K. Trace elements in end-stage renal disease. 1. Methodological aspects and the influence of water treatment and dialysis equipment. Blood Purif 1998;17(4):182-186.

21. Karahan Yilmaz S. Hemodiyalize giren hastalarda beslenme durumu ile kas gücü arasındaki ilişkinin değerlendirilmesi. Yüksek Lisans Tezi, Hacettepe Üniversitesi Sağllk Bilimleri Enstitüsü, Ankara, 2012.

22. Rakıcıŏ̆lu N, Nergiz R, Özkan Ş. Hemodiyaliz hastalarında beslenme durumu ve alışkanlıklarının değerlendirilmesi. Bes Diy Der 2005;32(1):13-20.

23. Fouque D, Vennegoor M, Ter Wee P, Wanner C, Basci A, Canaud B, et al. EBPG guideline on nutrition. Nephrol Dial Transplant 2007;22(suppl 2):ii45-ii87.

24. Sevim Y. Hemodiyaliz hastalarında beslenme durumu ve malnutrisyon. Yüksek Lisans Tezi, İstanbul Üniversitesi, Sağlık Bilimleri Enstitüsü, İstanbul, 2010.

25. Hosokawa S, Oyamaguchi A, Yoshida O. Trace elements and complications in patients undergoing chronic hemodialysis. Nephron 1990;55(4):375-379.

26. Hosokawa S, Nishitani H, Umemura K, Nishio T, Tomoyoshi T, Sawanishi K, et al. Relationship between haemodialysis anaemia and copper and zinc. Int Urol Nephrol 1985;17(4):365-371. 